\title{
Monitoring of Ground Forest Fire Impact on Heavy Metals Content in Edafic Horizons
}

\author{
Vasyl Popovych ${ }^{1 *}$, Andriy Gapalo ${ }^{1}$ \\ 1 Institute of Civil Protection, Lviv State University of Life Safety, Kleparivska Str. 35, Lviv, 79007, Ukraine \\ *Corresponding author's e-mail: popovich2007@ukr.net
}

\begin{abstract}
Fires in natural ecosystems cause catastrophic consequences on a global scale. These fires are caused by landscape-transforming factors, which include dust and gas pollution of the atmosphere, destruction of forests and living organisms, pollution of ecosystems with dangerous toxic compounds and heavy metals. The aim of the presented research is to investigate the influence of ground forest fires on the concentration of mobile forms of heavy metals in different soil horizons. Sampling of soils of pyrogenic origin was carried out from 4 plots according to operating standards on the territory of Rava-Rusky forestry near the village of Lavrykiv, Zhovkva district, Lviv region (Ukraine). Soil sampling for investigation of migration of heavy metals was carried out taking into account the number of years spent after burning of meadow vegetation and forest litter. The most contaminated with heavy metals is site \#2 (completely burned out 2 years before the experiment). There is a significant accumulation of cadmium in edaphic horizons $(0.31-0.66 \mathrm{mg} / \mathrm{kg})$, the value is close to the maximum allowable concentrations for soils $(0.7 \mathrm{mg} / \mathrm{kg})$. Also in this area the highest content of mobile forms of nickel $(1.52-2.80 \mathrm{mg} / \mathrm{kg}$ ) was detected, while the maximum allowable concentrations for soils is $4 \mathrm{mg} / \mathrm{kg}$. The lowest content of heavy metals is in the site \#1, which was exposed to fire long before the start of monitoring -3.5 years. Here the values of mobile forms of heavy metals are close to the background. Vegetation in burnt areas at the first year of post-pyrogenic development is characterized by spontaneous single species. In $2-3$ years it is characterized by a group arrangement. Complete natural overgrowth of the burnt area (natural vegetative reclamation) occurs 4-5 years after combustion. Monitoring the impact of ground forest fires on the concentration of heavy metals in edaphic horizons is important in terms of environmental renaturalization and the development of preventive measures for forest fires and fires in natural ecosystems.
\end{abstract}

Keywords: fire in natural ecosystems, forest fire, heavy metals, pollution monitoring

\section{INTRODUCTION}

The fire risk in the forests of Ukraine increases affected by human factors and weather conditions in spring and late summer. More than $98 \%$ of fires occur for this reason. The main cause of forest fires is the violation of fire safety requirements in forests during the period of high fire danger and burning of vegetation on agricultural lands and private households (Official website of State Committee of Forestry of Ukraine, 2021).

In the forest industry a departmental fire protection service basing on forest fire stations was set up. Forest protection from fires is provided by 307 state forestry and hunting enterprises, which include more than 1,700 forestries and 273 forest fire stations. The number of departmental fire protection staff is more than 13,000 people. A network of 502 fire observation towers has been created in the forests of Ukraine, 337 of them are equipped with modern television surveillance systems. State forestry enterprises have: 644 fire trucks, 467 forest fire modules on all-wheel drive chassis, 1,700 tractors with tillage equipment, 1,100 motor pumps, 8,900 knapsack forest sprayers and other technical equipment. Almost $80 \%$ of firefighting equipment is $30-40$ years old and needs retrofitting. Extinguishing forest fires at the initial stage is carried out by the relevant departments of forestry enterprises. When 
there is a threat of an emergency during a period of high fire danger the units of the State Emergency Service of Ukraine, regional state administrations and other bodies are involved (Official website of State Committee of Forestry of Ukraine, 2021). The dynamics of forest fires in Ukraine for 2010-2019 is shown in Figure 1.

In the first quarter of 2020 state enterprises of the State Forest Agency arranged: 2.3 kilometers of additional new fire lines, barriers; 11 thousand 800 kilometers of new firebreaks, maintenance of 27 thousand 700 kilometers of old firebreaks; 10,000 unplanned forest roads were blocked. In the forests along public roads and in resting places 8,100 agitation materials on fire-fighting issues were installed. 1089 speeches in mass media were organized. In the first quarter of 2020, the State Forest Guard conducted 3,800 raids, identified and fined 77 violators of fire safety rules in the amount of 10.9 thousand hryvnias. 127 cases of recovery of damages caused by fires were transferred to law enforcement authorities (Official website of State Committee of Forestry of Ukraine, 2021).

A lot of scientific works have been carried out for investigating the impact of fires in natural ecosystems on the environment. In the investigation made by Breulmann et al. (2002) during 1993 1997 in the Lambir Hills National Park revealed that heavy metals like $\mathrm{Co}, \mathrm{Cu}, \mathrm{Mn}, \mathrm{Ni}, \mathrm{Pb}$ and Ti showed higher values in 1997 compared to the previous years. It may be caused by pollution input from the haze caused by the extensive forest fires raging in Borneo and other parts of Southeast Asia. An input of heavy metals into tropical forests poses a serious threat to ecosystem.
The levels of polychlorinated dibenzo-p-dioxins and dibenzofurans (PCDDyFs) and polycyclic aromatic hydrocarbons (PAHs) formed during forest fires were measured in the burnt and in the corresponding unburnt soil samples. During a month after forest fires, the concentrations of PCDDyFs and PAHs in burnt soils were higher than in the corresponding unburnt soils but after five months their concentrations returned to the background values. The authors suggest that the ash is the main agent, influencing the concentration of PCDDyFs and PAHs in the soil (Breulmann et al., 2002).

The investigation of fire hazard of herbal plants made by Drach et al. [2020] proves that it depends significantly on their species and conditions. These differences can affect the occurrence of fires, as well as the rate of fire spread in grassy ecosystems. The highest thermal resistance is proper to Festuca arundinacea and Festuca pratensis. The largest ash residue is formed for Elymus repens and Phleum pretense. The humidity of the plants also affects the self-ignition temperature. At high humidity it is lower for the Elymus repens and Trifolium arvense, and at low humidity - for Elymus repens and Phleum pretense (Kim et al., 2003).

According to recent research made by Gutowski et al. (2020) a 10-year study of postfire beetle succession in natural ecosystem of Białowieża Primeval Forest, Poland, revealed that fires positively influence forest ecosystems. Comparative analysis of beetles sampled at burned and unburned (control) sites between treatments (fires) and over time showed that both alpha (average species richness) and gamma (pooled regional species richness) diversity

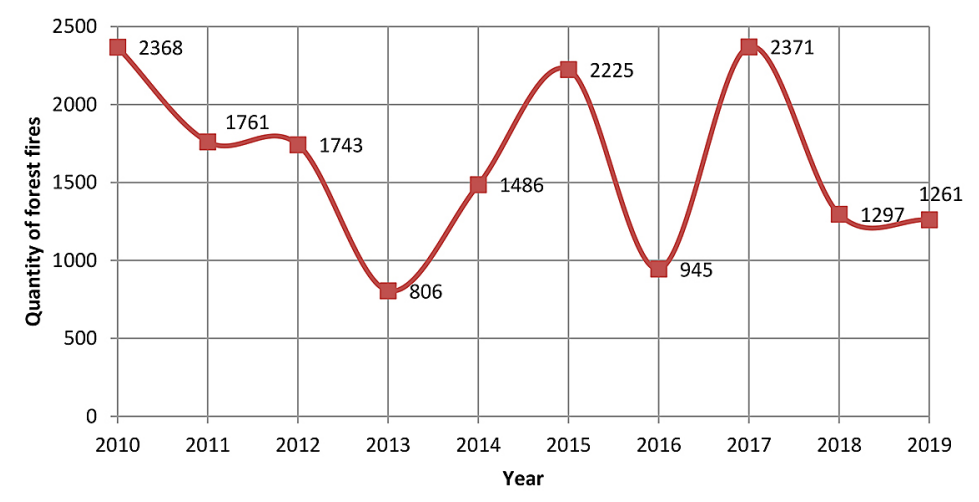

Fig. 1. The dynamics of forest fires in Ukraine for 2010-2019 (Official website of State Committee of Forestry of Ukraine, 2021) 
of beetle community in natural forest as well as density per sample was higher in burned forest than in control sites but these differences were disappearing over time since fire. Consequently, there is a positive role of forest fires in the restoration of the ecosystem.

The investigation of ashes collected immediately after a forest fire (Silva et al., 2015) revealed that $\mathrm{Ca}, \mathrm{S}, \mathrm{Mg}, \mathrm{K}$ and $\mathrm{Na}$ were the principal elements in the aqueous extracts of ash; two low molecular weight polycyclic aromatic hydrocarbons (phenanthrene and naphthalene) were also detected. Ecotoxicological screening of the aqueous extracts showed a decrease in the growth of two primary producers - Pseudokirchneriella subcapitata and Lemna minor, but there was no significant immobilization of Daphnia magna detected. From this we can deduce that short-time toxicity may be absent at higher trophic levels.

According to analysis of fires in Lviv region, Ukraine, the largest number of fires occurs at the beginning of the fire-dangerous period that coincides with the snow melting, as well as during harvesting. The frequency of fires on the flat lands closely depends on whether whilst the steppe and forest fires occurrence is less dependent on these indicators (Popovych and Renkas, 2019).

Based on the foregoing results of experimental research and statistics, it can be concluded that the impact of ground fires on the physicochemical properties of surface soil horizons is significant and requires detailed research for implementation of firefighting measures.

\section{MATERIALS AND METHODS}

The aim of the presented research is to investigate the influence of ground forest fires on the concentration of mobile forms of heavy metals in different soil horizons.

Sampling of soils of pyrogenic origin was carried out from 4 plots in accordance with the generally accepted standards on the territory of Rava-Ruska forestry near Lavrykiv, Zhovkva district, Lviv region (Ukraine). Soil sampling for the investigation of migration of mobile forms of heavy metals was carried out taking into account the burning age of meadow vegetation and forest litter. Soil samples were taken from depths of $5 \mathrm{~cm}, 10 \mathrm{~cm}$ and $20 \mathrm{~cm}$. Site 1 (samples 1 , 2,3 ) - young pine stands, a fire that occurred 3.5 years before the experiment, destroyed all forest litter, young growth and caused thermal destruction of the soil, lower parts of trunks and branches of Pinus sylvestris, that took root due to artificial overgrowing (2014). Site 2 (samples $4,5,6)$ - meadow vegetation dominates, which completely burned down 2 years before the experiment, the fire caused thermal destruction of the soil (2015). Site 3 (samples 7, 8, 9) - meadow vegetation dominates, which completely burned down 1.5 years before the experiment, the fire caused thermal destruction of the soil (2016). Site 4 (samples 10,11,12) - a model fire. As a result meadow vegetation was completely burned, the fire caused thermal destruction of the soil (2017). The model fire was set in compliance with fire safety requirements without transferring the fire to other unexplored areas (Rules of fire safety in

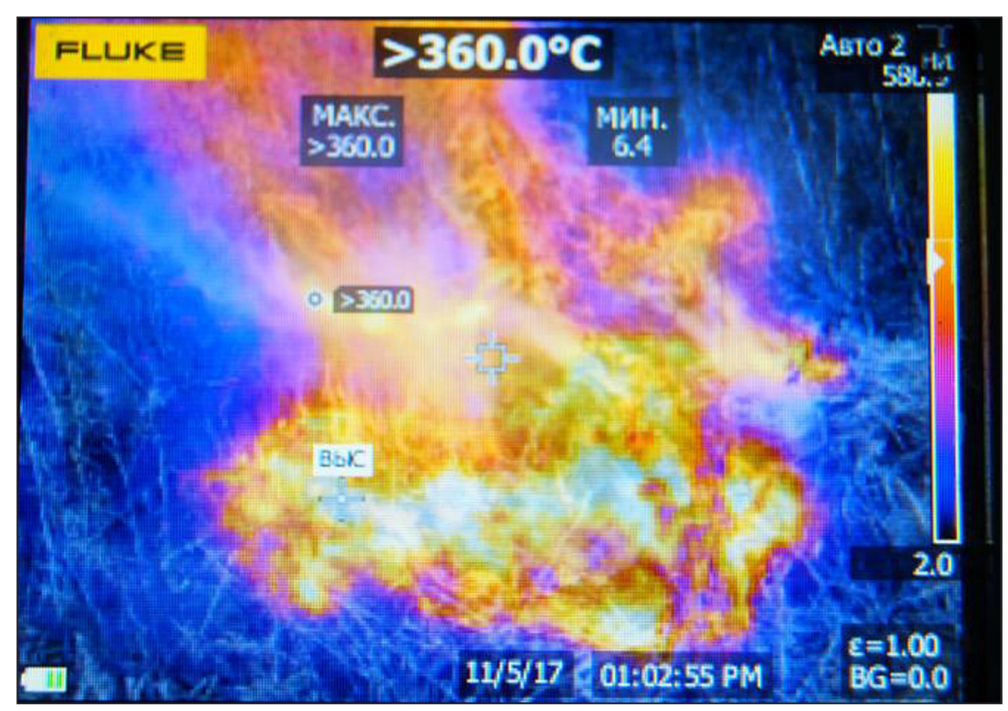

Fig. 2 - Model of ground forest fire 
the forests of Ukraine, 2004) Geographical coordinates of the model fire $-50.158510,23.783718$. Temperature regimes and the general appearance of the model fire are shown in fig. 2.

Sampling was carried out during the fire danger period in May, 2017. The ambient temperature was $+22{ }^{\circ} \mathrm{C}$, the wind was from the east, speed of $2.5 \mathrm{~m} / \mathrm{s}$. Land - water-saturated arable land. Soil samples were delivered to the Laboratory of Industrial Toxicology (Lviv, Ukraine) for conducting analysis on $\mathrm{Cu}, \mathrm{Cd}, \mathrm{As}, \mathrm{Ni}, \mathrm{Co}, \mathrm{Mn}$ content.

Research instruments: electronic scales "Pioneer PA 214C" (certificate of calibration KLM 774 from 26.10.2017), diagnostic kit with a microscope "Mikmed-6", atomic absorption spectrophotometer C-115.M1 (certified №01-2015.1, certificate of calibration UA/37/171129/001049 dated 22.11.2017), photoelectric colorimeter KFK-3 (certified №9004484, calibration certificate KL770 dated 24.10.2017).

Determination of toxic elements was carried out according to the methods certified by state standards of Ukraine: DSTU 4770.9, DSTU 4770.3, DSTU 4770.7, DSTU 4770.5, DSTU 4770.1 , as well as "Guidelines for the determination of arsenic in soils by photometric method" from 26.02.1993 (the average value of the relative measurement error with a confidence level of 0.95 does not exceed $18 \%$ ).

Statistical processing of the obtained data was performed using correlation analysis.

Investigation of the heavy metals migration in soils of pyrogenic origin are important for monitoring the impact of forest fires on the environment and restoration of disturbed areas.

\section{RESULTS AND DISCUSSION}

The investigation of heavy metals accumulation in the edaphic horizons of post-pyrogenic soils showed that most of them are deposited in site 2 (samples 4, 5, 6) and site 4 (samples 10, 11, 12). In the most contaminated site 2 a significant accumulation of cadmium in the edaphic horizons $(0.31-0.66 \mathrm{mg} / \mathrm{kg})$ was determined. Its value is close to the maximum allowable concentration for soils $(0.7 \mathrm{mg} / \mathrm{kg})$. The highest content of mobile forms of nickel $(1.52-2.80 \mathrm{mg} / \mathrm{kg})$ was observed also in site 2 , by comparison the maximum permissible concentration for soils is $4 \mathrm{mg} / \mathrm{kg}$. The high rates of mobile forms of heavy metals in site 2 are caused by its location close to the local highway, where the additional contamination occur due to the transport operation. In site 4 the excessive content of heavy metals in the soils is due to the recent the ground forest fire, as a result all the vegetation burned to the mineral layer.

The lowest content of heavy metals is in the site 1 , which was exposed to fire for the longest time -3.5 years before the start of monitoring. Here the content of mobile forms of heavy metals are close to the background. Such indicators are absolutely acceptable; it is obvious that the ecosystem self-restores due to natural vegetative reclamation within 3-4 years after exposure to pyrogenic factors (Fig. 3).

In general, in all post-pyrogenic areas, the highest content of mobile forms is observed for nickel, manganese and cobalt, as well as for cadmium and arsenic, which are extremely toxic. The

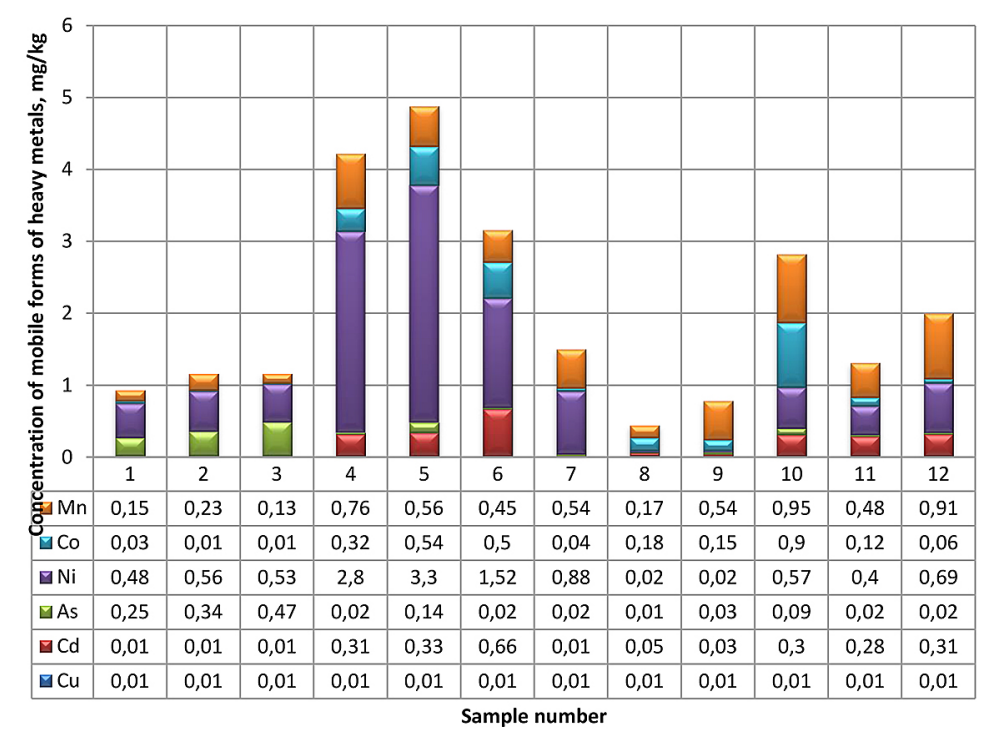

Fig. 3 - Heavy metals content in the samples, $\mathrm{mg} / \mathrm{kg}$ 
copper content in the soils is close to the background (Fig. 4).

Toxic effect of nickel deposited in tissues consists in the induction of acute and chronic inflammatory processes, changes in the functional activity of macrophages; vasoconstrictive effect; modification of metabolism of lipids, proteins (enzymes), glycogen, glucose, DNA, RNA; enhancement of lipid peroxidation; increasing the permeability of biological membranes; destruction of mitochondria, changes in energy metabolism (Drohomyretska et al., 2009). Inhaled poisoning of mice with $\mathrm{NiSO}_{4}, \mathrm{Ni}_{3} \mathrm{~S}_{2}, \mathrm{NiO}$ compounds was performed for 6 hours a day, 5 days a week. Immunotoxicity of these compounds was determined in 65 days. The $\mathrm{Ni}_{3} \mathrm{~S}_{2}$ concentration of $1.8 \mathrm{mg} \mathrm{Ni} / \mathrm{m}^{3}$ led to a decrease in thymus mass, an increase in the number of pulmonary lymph nodes, a decrease in antibody-producing cells. The results indicate that the inhalation of nickel may have different effects on the immune system of mice depending on the dose and physicochemical form of the nickel compound. These nickelinduced changes can contribute to significant immunofunction (Haley et al., 1990).

Manganese in soils is in the form of divalent, tri- and tetravalent ions. Manganese compounds are well soluble, especially in acidic media. In the soil, manganese can replace the exchange bases $-\mathrm{Ca}^{2+}$ and $\mathrm{Mg}^{2+}$, and in the soil solution forms complexes with organic matter (mainly with fulvic acids). With iron hydroxides, manganese forms iron-manganese heads (Vasilyev and Chashchin, 2011). Toxic effects of manganese on humans and warm-blooded animals are associated with damage to the central nervous system, where it causes organic changes of extrapyramidal nature, in severe cases-parkinsonism. The extrapyramidal insufficiency in the case of chronic manganese poisoning is based on a lesion of the dopaminergic system of the brain. Inhibition of catecholamine biosynthesis is associated with the effect of manganese on oxidative enzymes localized on mitochondria, where manganese accumulates. Imbalance in the biosynthesis of catecholamines has an impact on behavior and changes in the mental state, in the case of chronic manganese poisoning. But manganese is also a polytropic poison that also affects the lungs, cardiovascular and hepatobiliary systems, affects erythropoiesis, embryogenesis, causes allergic and mutagenic effects (Pedan, 2013; Bezdil et al, 2016).

Unlike other metals, soil cobalt is non-toxic. The content of its mobile compounds is determined for assess the adequacy of microelement nutrition of plants, or in case of risk of polyelement contamination-to establish possible effects of antagonism-synergism between cobalt and other heavy metals that can significantly affect the accumulation of toxic metals in plant tissues (State standard DSTU 4770.5, 2007).

Cadmium adversely affects biochemical processes and physiological functions in animals and humans. The peculiarity of the harmful effects of cadmium is its rapid absorption by the body and slow excretion, which leads to the accumulation of this metal in tissues. Cadmium accumulates mainly in the liver and kidneys (Barbier et al.,

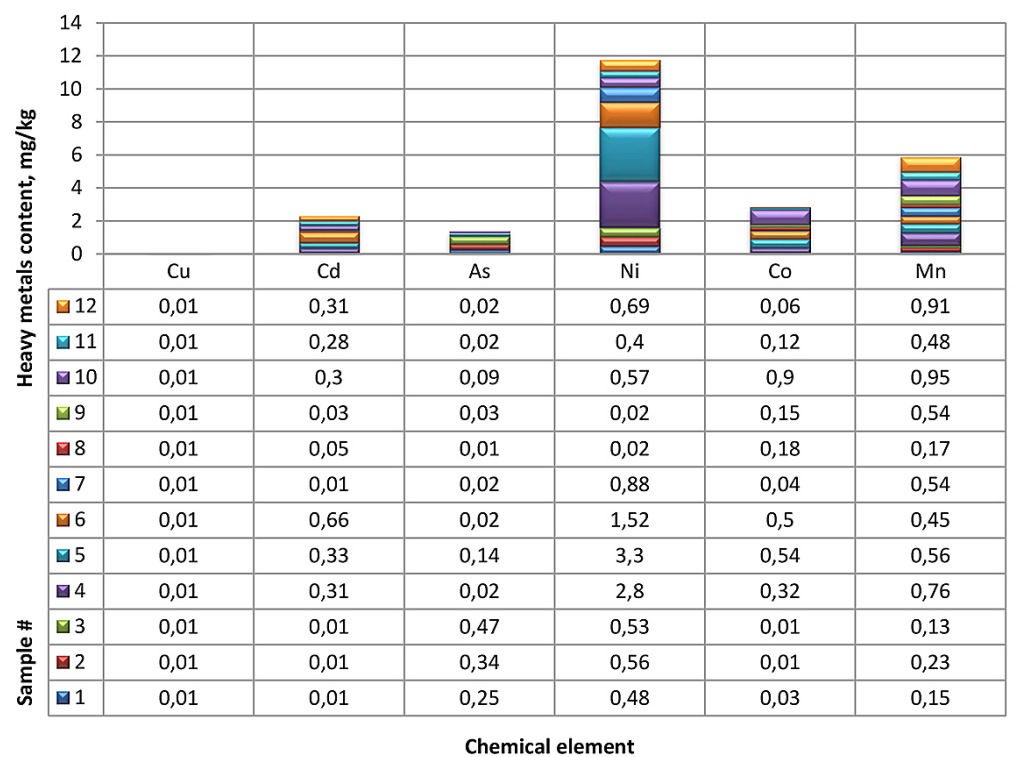

Figure 4. Total content of each heavy metal in samples, $\mathrm{mg} / \mathrm{kg}$ 
2005) and has a long half-life (up to 30 years), i.e. in the applied aspect, it can be considered that for animals the deposition of cadmium in the body is lifelong. The toxic effect of cadmium is most pronounced for the kidneys (Corredor, 2004) the reabsorption of amino acids, glucose, phosphorus and oligopeptides. In bone tissue under the influence of cadmium calcification processes are disrupted. Cadmium causes cancer, can cause mutations, destruction of the DNA chain, chromosomal aberrations. Cadmium affects the transmembrane transmission of hormonal signals in cells (Nam and Lee, 2006), reproductive function and peroxidation processes in the body. It alters the activity of protein kinase $\mathrm{C}$ and mitogen protein kinase, disrupts the metabolism of cyclic AMP (Phillips et al., 2004). Low doses of cadmium in animals stimulate cell apoptosis, in the case of increasing the dose of cadmium in cells, necrotic changes begin (Paranyak et al., 2007).

For natural and agricultural soils, $\mathrm{Cd}$ is not a pollutant, and its concentration coefficient averages from 0.15 to 0.95 . The nature of Cd migration in the profile of sod-podzolic soils is eluvialilluvial, gray podzolic - radial, and in dark gray podzolic soils $\mathrm{Cd}$ is distributed evenly throughout the soil profile (Myslyva, 2013). In soluble form, cadmium is more toxic than is indicated by MAC of its mobile forms. In the soil solution, cadmium can form complex ions of $\mathrm{CdCl}^{+}, \mathrm{CdOH}^{+}, \mathrm{Cd}-$ $\mathrm{HCO}_{3}{ }^{+}, \mathrm{Cd}(\mathrm{OH})_{3}^{-}$and organic complexes. It can be assumed that the mobility of these ions will strongly depend on the concentration of calcium, $\mathrm{pH}$ of the soil solution and other chemical factors that will reduce the mobility of cadmium ions, and hence its toxic effects (Plaksienko et al., 2020).

Arsenic is a poison of resorptive action. The acute toxicity of its compounds is lower compared to other metals. In dissolved form, arsenic occurs in tri- and pentavalent forms $\left(\mathrm{H}_{2} \mathrm{AsO}_{3}, \mathrm{H}_{3} \mathrm{AsO}_{4}\right)$, mainly anionic, in the form of salts-arsenites and arsenates, as well as in the form associated with organic ligands. Sources of arsenic pollution include wastewater from concentrators, tanneries, pesticide companies, metallurgical waste, landfill discharges, and leaching from agricultural land where pesticides are used. The ratio of natural and man-made sources of arsenic pollution is 1:3 (Moore and Ramamurti, 1987; Moiseenko, 2009). Contamination of the aquatic environment with inorganic water-soluble arsenic significantly affects the fertility of fish. This manifests in reducing the number of eggs laid and reducing the number of pairs of broodstock used in spawning. Under the influence of the toxicant, the level of hepatic vitellogenin transcriptors decreases by 1.5 times, dysfunction of the hypothalamic-pituitary system and sperm proliferation occur (Davey et al., 2007).

As for the concentration distribution of investigated heavy metals in post-pyrogenic edaphic horizons, we can state that their highest content is in the range of $0-1 \mathrm{mg} / \mathrm{kg}$. These are mainly heavy metals such as copper and arsenic $(0.01-0.47 \mathrm{mg} /$ $\mathrm{kg}$ ). Accumulation of cadmium (up to $0.66 \mathrm{mg} / \mathrm{kg}$ ) and cobalt (up to $0.9 \mathrm{mg} / \mathrm{kg}$ ) is slightly higher, which corresponds to the range $0-1 \mathrm{mg} / \mathrm{kg}$. Nickel predominates in all distribution ranges $(0-1,1-2$, $2-3,3-4 \mathrm{mg} / \mathrm{kg}$ ). The distribution of heavy metals depending on their concentration in postpyrogenic edaphic horizons is shown in Figure 5.

Pearson's correlation coefficients for the indicators of the concentration of mobile forms of heavy metals in post-pyrogenic edaphic horizons made it possible to assess the interdependence between the total concentrations of individual heavy metals. The highest positive correlation coefficient corresponds to cobalt and cadmium (0.627099), i.e. these elements evenly increase or decrease their content against to each other. The highest negative correlation coefficient corresponds to manganese and arsenic (-0.57968), i.e. as $\mathrm{Mn}$ increases, the As concentration decreases and vice versa. A low correlation (0.5) is observed for the rest of the elements. There is no relationship between the concentrations of $\mathrm{Ni}$ and As, i.e. salts of these elements do not affect each other and are soluble in the soil (Table 1).

The most effective technologies for the restoration of devastated areas due to the pyrogenic factor are recultivation and vegetative reclamation. Note that in areas where grtound forest fires took place, even without human intervention, there are processes of overgrowing with vegetation, the so-called post-pyrogenic successions. Such post-pyrogenic successions were observed on the territory of the investigated area. Vegetation in burnt areas in the first year of post-pyrogenic development is characterized by spontaneous single species. In 2-3 years group arrangement appear. Complete natural overgrowth of the burned area (natural vegetative reclamation) occurs at $4^{\text {th }}-5^{\text {th }}$ year after combustion. In Ukraine, there is also a practice of artificial cultivation of vegetation (Scots pine) on fires. This applies to the southern regions of Ukraine, where in 2007 some of the largest forest fires in history took place. 


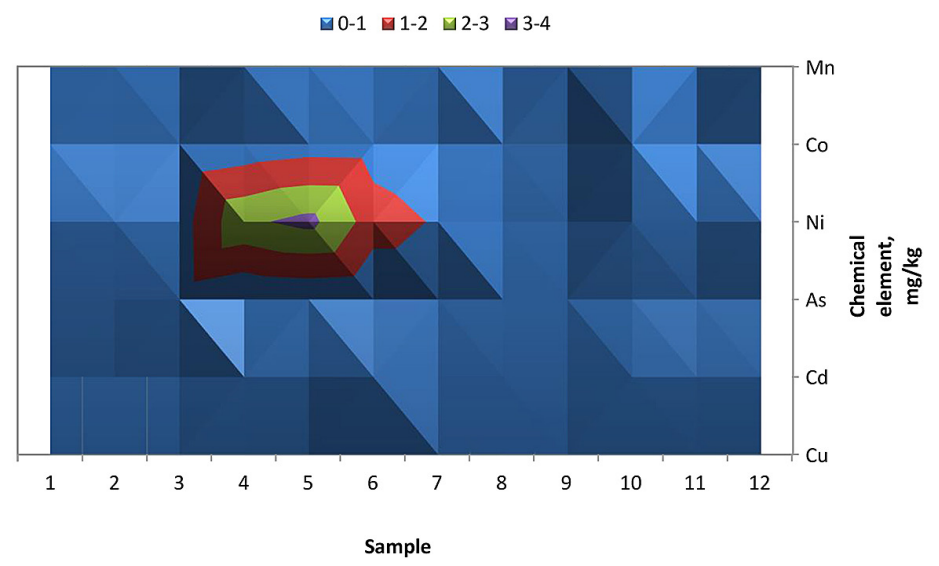

Figure 5. The distribution of heavy metals depending on their concentration in postpyrogenic edaphic horizons, $\mathrm{mg} / \mathrm{kg}$

Table 1. Pearson's correlation coefficients for the indicators of the concentration of mobile forms of heavy metals in post-pyrogenic edaphic horizons

\begin{tabular}{|c|c|c|c|c|c|c|}
\hline & $\mathrm{Cu}$ & $\mathrm{Cd}$ & $\mathrm{As}$ & $\mathrm{Ni}$ & $\mathrm{Co}$ & $\mathrm{Mn}$ \\
\hline $\mathrm{Cu}$ & & 0 & 0 & 0 & 0 & 0 \\
\hline $\mathrm{Cd}$ & & & $-0,45735$ & 0,514606 & 0,627099 & 0,504914 \\
\hline $\mathrm{As}$ & & & & $-0,11492$ & $-0,3018$ & $-0,57968$ \\
\hline $\mathrm{Ni}$ & & & & & 0,407292 & 0,312699 \\
\hline $\mathrm{Co}$ & & & & & & 0,553345 \\
\hline $\mathrm{Mn}$ & & & & & & \\
\hline
\end{tabular}

\section{CONCLUSIONS}

Thus, during investigation of the impact of ground forest fires on the concentration of mobile forms of heavy metals in different soil genetic horizons, it was found that the highest concentration is observed in the upper layers, except for the area that has undergone long-term pyrogenic exposure ( 3.5 years before monitoring). That is, the ecological restoration of the territory occurs at $3^{\text {rd }}-4^{\text {th }}$ year after the pyrogenic factor.

In all studied post-pyrogenic areas, the highest content of mobile forms is observed for nickel, manganese and cobalt. Also there is a high content of cadmium and arsenic in the edaphic horizons, which are extremely toxic. The copper content in the soils is close to the background. The highest content of heavy metals is in the range of $0-1 \mathrm{mg} /$ $\mathrm{kg}$. These are mainly heavy metals such as copper and arsenic $(0.01-0.47 \mathrm{mg} / \mathrm{kg})$. The accumulation of cadmium (up to $0.66 \mathrm{mg} / \mathrm{kg}$ ) and cobalt (up to $0.9 \mathrm{mg} / \mathrm{kg}$ ) is slightly higher, which corresponds to the established range of $0-1 \mathrm{mg} / \mathrm{kg}$. Nickel predominates in all distribution ranges.

Pearson's correlation coefficients between the indicators of the concentration of mobile forms of heavy metals in post-pyrogenic edaphic horizons made it possible to assess the interdependence between the total concentrations of individual heavy metals. The highest positive correlation coefficient corresponds to cobalt and cadmium (0.627099), i.e. these elements evenly increase or decrease their content against to each other. The highest negative correlation coefficient corresponds to manganese and arsenic (-0.57968), i.e. as $\mathrm{Mn}$ increases, the As concentration decreases and vice versa.

Monitoring the impact of ground forest fires on the concentration of heavy metals in edaphic horizons is important in terms of environmental renaturalization and the development of preventive measures with regard to forest fires and fires in natural ecosystems.

\section{REFERENCES}

1. Official website of State Committee of Forestry of Ukraine. Electronic resource. http://dklg.kmu. gov.ua/forest/control/uk/publish/article?art_ id $=118927 \&$ cat_id $=118926$ [in Ukrainian]

2. Breulmann G., Markert B., Weckert V., Herpin U., Yoneda R., Ogino K. 2002. Heavy metals in emergent trees and pioneers from tropical forest with 
special reference to forest fires and local pollution sources in Sarawak, Malaysia. The Science of the Total Environment. 285. 107-115.

3. Kim E.-J., Oh J.-E., Chang Y.-S. 2003. Effects of forest fire on the level and distribution of PCDDyFs and PAHs in soil. The Science of the Total Environment. 311. 177-189.

4. Drach K.L., Kuzyk A.D., Tovarianskyi V.I., Yemelianenko S.O. 2020. Fire dangerous properties of the most common plants of grass ecosystems in Ukraine. Ecologia Balkanica. 12, 1. 147-154.

5. Gutowski J.M., Sucko K., Borowski J., Kubisz D., Mazur M.A., Melke A., Mokrzycki T., Plewa R., Żmihorski M. 2020. Post-fire beetle succession in a biodiversity hotspot: Bialowieza Primeval Forest. Forest Ecology and Management. 461, 117893. https://doi.org/10.1016/j.foreco.2020.117893

6. Silva V., Pereira J.L., Campos I., Keizer J.J., Gonçalves F., Abrantes N. 2015. Toxicity assessment of aqueous extracts of ash from forest fires. Catena. 135. 401-408. http://dx.doi.org/10.1016/j. catena.2014.06.021

7. Popovych, V., Renkas, A. 2019. Features of Landscape Fires Occurrence (Based on the Example of Lviv Region of Ukraine). Ecologia Balkanica. 11, 2. 99-111.

8. Rules of fire safety in the forests of Ukraine, approved by the Order of the State Committee of Forestry of Ukraine dated 27.12.2004 №278. [in Ukrainian]

9. Drohomyretska I.Z., Mazepa I.V., Mazepa M.A. 2009. Immunotoxicity of nickel and its compounds. Modern problems of toxicology. 3-4. 25-31. [in Ukrainian]

10. Patrick J. Haley, George M. Shopp, Janet M. Benson, Yung-Sung Cheng, David E. Bice, Michael I. Luster, June K. Dunnick, Charles H. Hobbs. 1990. The Immunotoxicity of Three Nickel Compounds following 13-Week Inhalation Exposure in the Mouse. Toxicological Sciences. 15, 3. 476-487. https://doi.org/10.1093/toxsci/15.3.476

11. Vasilyev A., Chashchin A. 2011. Heavy metals in the soils of Chusovoe: assessment and diagnosis of pollution. Perm: FGBOU VPO Perm GSHA. [in Russian]

12. Pedan L.R. 2013. Prevention of environmental factors effect on health due to the trace element manganese. Hygiene of populated areas: Coll. Science. Wash. 62. 325-345. [in Ukrainian]

13. Bezdil R.V., Pushkareva-Bezdil T.M., Shchetyna M.A. 2016. Content of heavy metals in rabbit farm waste and their environmentally safe disposal. Scientific Bulletin of NLTU of Ukraine. 26.1. 162-170. [in Ukrainian]

14. State standard DSTU 4770.5. 2007. Soil quality. Determination of the content of mobile cobalt compounds in the soil in a buffer ammonium acetate extract with a $\mathrm{pH}$ of 4.8 by atomic absorption spectrophotometry. [in Ukrainian]

15. Barbier O., Jacquillet G., Tauc M., Cougnon M., Poujeol P. 2005. Effect of heavy metals on, and handling by, the kidney. Nephron Physiol. 99 (4). 105-110. https://doi.org/10.1159/000083981

16. Antonio G., Corredor L. 2004. Biochemical changes in the kidneys after perinatal intoxication with lead and or cadmium and their antagonistic effects when coadministered Ecotoxicol Environ Saf. 57(2), 184-189.

17. Nam D.H., Lee D.P. 2006. Monitoring for $\mathrm{Pb}$ and Cd pollution using feral pigeons in rural, urban, and industrial environments of Korea. Sci. Total Environ. 15. 357 (1-3). 288-295.

18. Phillips C.J., Chiy P.C., Omed H.M. 2004. The effects of cadmium in feed, and its amelioration with zinc, on element balances in sheep. J. Anim. Sci. 82 (8). 2489-2502.

19. Paranyak R.P., Vasiltseva L.P., Makukh Kh.I. 2007. Ways of heavy metals entry into the environment and their impact on living organisms. Biology of animals. 9, 1-2. 83-89. [in Ukrainian]

20. Myslyva T.M. 2013. Lead and cadmium in the soils of natural and agricultural landscapes of Zhytomyr Polissya. Bulletin of Zhytomyr National Agroecological University. 1 (1). 36-49. [in Ukrainian]

21. Plaksienko I.L., Kulyk M.I., Halytska M.A., Dychenko A.S. 2020. Ecotoxicological aspect of soil contamination with lead and cadmium. Proceedings of the II International Scientific and Practical Conference "Environmental problems and environmental management in the context of sustainable development". 37-39. [in Ukrainian]

22. Moore J., Ramamurti W. 1987. Heavy metals in natural waters. Moscow. [in Russian]

23. Moiseenko T. I. 2009. Aquatic ecotoxicology. Theoretical and applied aspects. Institute of Water Problems of the Russian Academy of Sciences. Moscow, Nauka. [in Russian]

24. Jennifer C. Davey, Jack E. Bodwell, Julie A. Gosse, Joshua W. Hamilton. 2007. Arsenic as an Endocrine Disruptor: Effects of Arsenic on Estrogen ReceptorMediated Gene Expression In Vivo and in Cell Culture. Toxicological Sciences. 98, 1. 75-86. https:// doi.org/10.1093/toxsci/kfm013 